\title{
MULTIPLE LINEAR REGRESSION MODEL OF GOLDEN APPLE'S FAILURE CHARACTERISTICS UNDER REPEATED COMPRESSIVE LOAD
}

\author{
Csaba Farkas, László Fenyvesi, Károly Petróczki
}

\begin{abstract}
In this paper, the multiple linear regression model of mechanical properties related to the failure mechanism of apple tissue under repeated compressive load was investigated. More refined failure characteristics may lead to improved processing and logistics aspects of the given fruits. For our study, the following failure-related factors are considered during the cyclic measurements of Golden Delicious apples: the viscoelastic parameters, the dissipated energy, and the rupture point of the cell-structure, which is described with the time to failure parameter (TTF). For the determination of viscoelastic components, the three element Poynting-Thomson body was applied, and a closed-loop control system is identified with the measured creep data. From the hysteresis loop - in each cycle of the force-deformation parametric curve - the dissipated energy can be calculated with a numeric integration method. The rupture point of the fruit tissue - where the measuring pin is breaking through the peel and the cortex - is observed with a high-framerate video analysis, so that the time index of the failure point can be evaluated. The focus is to define the influence of the mentioned factors to the TTF parameter of the examined fruit material. During the statistical evaluation of the resulted data, the failure of time can be successfully determined with a multiple lienar regression model of the determined viscoelastic and dissipated energy variables. With the resulted equation, the failure time of Golden Delicious apples can be predicted based on the measured failure-related parameters obtained during the compressive load tests.
\end{abstract}

Keywords: repeated load; fruit damage; analysis of variance; time to failure; mechanical fatigue

\section{INTRODUCTION}

Studying the damage resistance and failure susceptibility of fruits are one of the most important topics in the area of food processing and logistics. A very significant amount of the agricultural and horticultural crops never gets to the costumer, because the mechanical effects are often leading to a failure in the cell structure and consequential spoiling of the product, decreasing market value. Failure characteristics of fruit materials can be described with many different approaches. During destructive compressive tests, the stress-deformation curves of biological materials have been investigated from several aspects.

Fruits and vegetables are usually described with viscoelastic models (Mohsenin, 1986), where the creeping and stress relaxation phenomenon have an important role; as Sitkei (1986) pointed, the creeping behaviour occurs in more technological and manipulating process (e.g. the settling of silage and granular piles, or the deformation of fruits by their dead weight), but the relaxation time is also an important factor in the area of food industry, e.g. in the case of juice industry (Gorji Chakespari et al., 2010). The fruit firmness is also determined with certain parts of the relaxation curve (Blahovec, 1996). The destructive fruit and vegetable researches are based on the evaluation of the force-deformation characteristics, that resulted during creep or stress relaxation tests (Tscheuschner and Doan, 1988; Zhao et al., 2017; Miraei Ashtiani et al., 2019). These examinations are usually performed with different universal or custom loading devices.

Since most of the postharvest operations are affecting the crops with impact or repeated compressive mechanical forces, the laboratory tests aim to reproduce these circumstances, and observe the fruit material during its colliding or its fatigue process. Fruit-to-fruit damage or collusion with rigid materials can be examined with a pendulum impacting device (Ferreira et al., 2008; Wang et al., 2018), or firmness measurements can be performed with drop tests (Wang et al., 2009; Vursavus, Kesilmis and Oztekin, 2017). In other cases, the dropping of pear fruits (Yousefi, Farsi and Kheiralipour, 2016), the mechanical interaction between two apples (Ahmadi, Barikloo and Kashfi, 2016), or the collusion against a rigid flat plate is simulated with finite element analysis (Dintwa et al., 2008).

For the reproduction of the repeated mechanical effects from various manipulations, some research already 
experimented with cyclic load: McLaughlin and Pitt (1984) investigated a cell-rupture model during their fatigue examinations, while Lee, Tan and Waluyo (2012) and Bohdziewicz and Czachor, (2016) studied the dissipated energy during cyclic load conditions.

Mohsenin (1986) and Sitkei (1986) specified two typical point in the deformation characteristics of the biological materials, which are related to the mechanical failure: the biological yield, and the rupture point. The biological yield point is an initial fracture inside the microstructure of the cell system, which can lead to a more extent damaged volume, and ultimately, to spoiling. However, the biological systems are capable to regenerate, it can be a reasonable limit for the mechanical effects to stay under this value. The rupture point means a significant damage in the biostructure, which indicates the mechanical failure. It often comes with a clearly visible breaking point at the deformation graph, but in some cases - when the loading force is fast - the determination of this time instant can be more difficult.

The applied and absorbed mechanical energy is greatly responsible for the volume of the resulting fruit damage during an impact, a compression, or a vibration process (Hussein, Fawole and Opara, 2018). The dissipated energy is strongly related to the failure mechanism of the biological materials, which can be calculated from the hysteresis loop of the stress-strain characteristics; for the investigation of the energy indicators, the area between the loading and unloading curve is usually observed (Ciupak and Gladyszewska, 2011; Lee, Tan and Waluyo, 2012; Diels et al., 2016). In case of certain apple types, the hysteresis parameters are showing a significant relationship with viscoelastic properties (Lee, Tan and Waluyo, 2016). The momentum-formula is also applied for the determination of energy-balance, when the fruits are exposed to colliding during different drop tests (Lien and Ting, 2014; Stropek and Golacki, 2013).

The energy dissipation related to fatigue degradation and cracking is an active research area in other fields as well; although, the dissipated energy under the hysteresis loop can be determined in each cycles of a repeated mechanical load, it is often questioned, that it is fully or partially reversible, and whether can be linked to the damage or not (Kim, Roque and Birgisson, 2006; Kahirdeh and Khonsari, 2015).

From the aspect of fruit bin and package design, the effect of transportation to the fruit piles is usually inspected during simulated examinations with vibration-pads. The most dangerous frequencies - that causing the highest volume of fruit damage - are determined with accelerometer sensors. According to the consilient report of different studies, the frequency range under $10 \mathrm{~Hz}$ is the most dominant, and it is responsible for the most extensive losses (Fischer et al., 1992; Hinsch et al., 1993; Vursavuş and Özgüven, 2004). In order to keep the quality of piles as good as possible besides the bin and package optimizing - an appropriate transport-planning can be a viable solution as well, if the poorly maintained road segments can be avoided (Springael, Paternoster and Braet, 2018).

In the case of biological or other viscoelastic materials, the creeping curve is divided into different phases, where the last section is beginning with a crack initiation point, which is indicating the failure of the material. However, the literature is not specifying the precise determination of this occurrence, the accurate identification can be very important. Since the stress-strain characteristics of fruits are not always indicating the rupture point clearly and accurately (especially in the case of fast loading speeds, which cause a steep rising in the deformation curve), a image-processing based observation with high framerate can be set for the determination of the failure time - when the measuring pin is getting through the damaged fruit peel and cortex during cyclic compressive testing. Obtaining this parameter, our study aims to explore the influence of the dissipated energy and the viscoelastic parameters to the fatigue mechanism of the selected Golden Delicious apple texture.

\section{Scientific hypothesis}

Hypothesis H1: The time to failure (TTF) parameter of pome fruits can be described with the multivariate linear regression of viscoelastic properties and an indicator of dissipated energy.

Hypothesis H2: Our previous study reported (Farkas, Fenyvesi, and Petróczki, 2019b), that the elastic modulus parameters from the viscoelastic model are not showing any dependence of the frequency in case of Golden Delicious apples. The viscous part relates to the applied frequency settings in a non-linear way, so we assume, that the frequency variables will not have any role on the determination of the failure time either.

\section{MATERIAL AND METHODOLOGY}

To perform the cyclic load measurements, the custom developed DyMaTest device is applied (Fenyvesi, 2007; Petróczki and Fenyvesi, 2014). The examined apple is placed into a sand bed, where a measuring pin of $4 \mathrm{~mm}$ diameter is loading the peel surface in a $10 \mathrm{~mm}$ deformation range. The fruits were measured and modelled as a structure of peel and cortex.

Before the investigations, the creeping response of the prepared sand is tested with control measurements. In order to perform this inspection, a solid ball bearing of $32 \mathrm{~mm}$ diameter is loaded. The deformation graph is not showing any creeping behaviour in the measuring range of the photoelectric sensor. The sand is dried and filtered with a mesh layer-by-layer (Pillinger et al., 2018), then it is compacted with a metal tamper.

For the current examinations, a cosinusoidal forcefunction was adjusted in the software environment of the computer-controlled instrument:

$$
F_{m}(t)=F_{\max }(1-\cos (\omega t)),
$$

where $\mathrm{Fm}_{\mathrm{m}}$ is the measured cosinusoidal load function, $\mathrm{F}_{\max }$ is the amplitude of the force $(\mathrm{N})$, and $\omega$ is the angular velocity of the loading (s-1).The deformation response is also cosinusoidal, and with the consideration of the creeping process, it is described with the following equation before the rupture point:

$$
w_{m}(t)=j t+k+w_{\max }(1-\cos (\omega t-\delta)),
$$

where $\mathrm{Wm}$ is the measured deformation function, Wmax is the amplitude of the deformation $(\mathrm{mm}), \mathrm{j}$ and $\mathrm{k}$ are the coefficients of the linear part of creeping ( $\mathrm{j}$ denotes the slope and $\mathrm{k}$ is the $\mathrm{y}$-intercept), $\omega$ is the angular velocity ( $\mathrm{s}-1)$, while $\delta$ is the phase angle difference between force and deformation. 


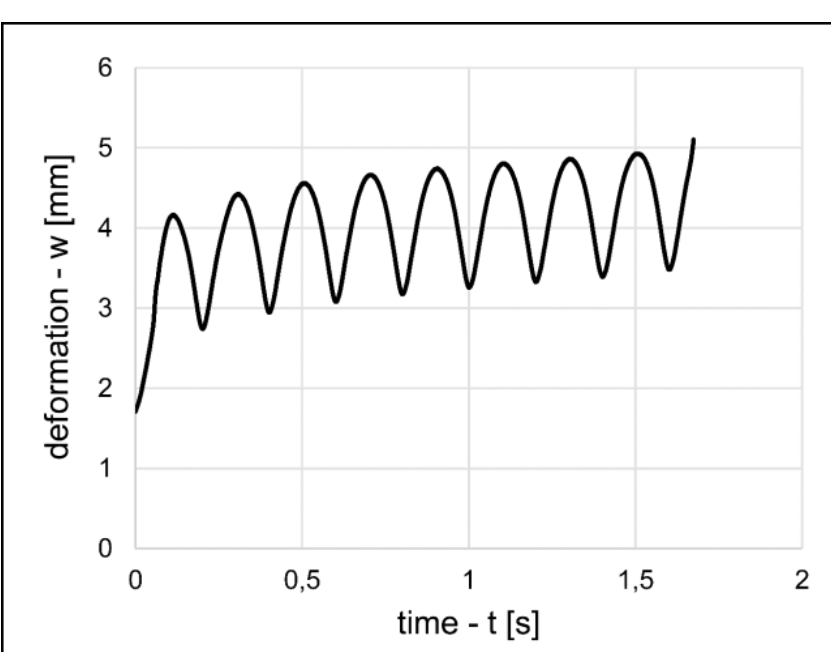

(a)

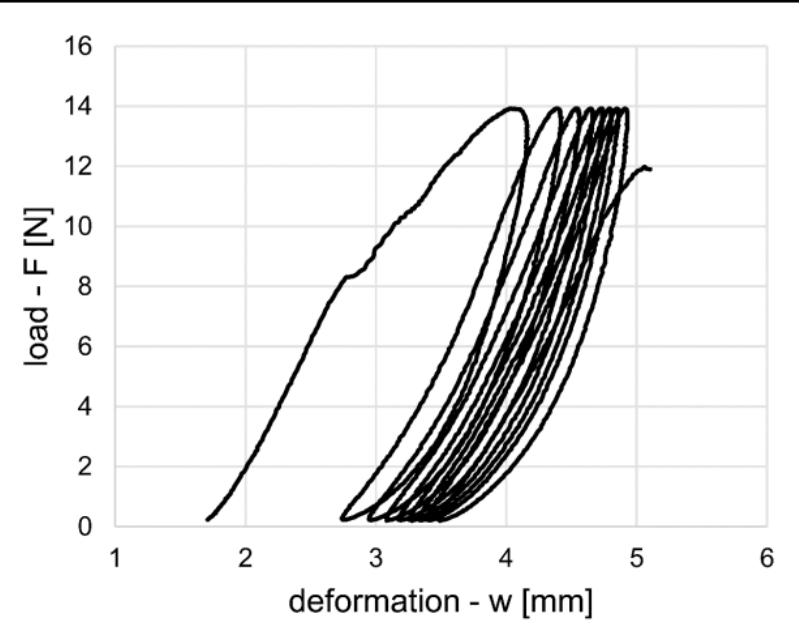

(b)

Figure 1 Typical deformation-time (a) and force-deformation (b) characteristics of Golden Delicious apple tissue.

Because of the repeated compressive examinations, the tested biomaterial is showing a dynamic creeping behaviour: while the mean value of the cosinusoidal load is constant, the curves - that envelope the maximum and minimum points of the deformation - have a similar character to the creeping during a constant load. This dynamic creeping can be seen at Figure 1 (a), where the graph of deformation as a dependent of time is presented.

The resulted deformation curves are investigated before the rupture point, where the irreversible failure of the fruit texture is certainly occurring. Because of the relatively fast rising nature of the loading curve, the breaking point is not always showing itself, so this specific occasion is determined with a camera, which is capable of a recording with 240 frames per second. The rupture moment - when the measuring pin is getting through the peel - is registered during the frame analysis (shown in Figure 2) as a time parameter and referred as 'time to failure' in the present study (TTF - Gnedenko et al., 1999).

Figure 1 (b) is illustrating the force-deformation characteristic of the examined apples, where the areas between the loading and unloading curves are representing the dissipated energy of each cycle. The calculation of this internal loop area is based on the following general formula:

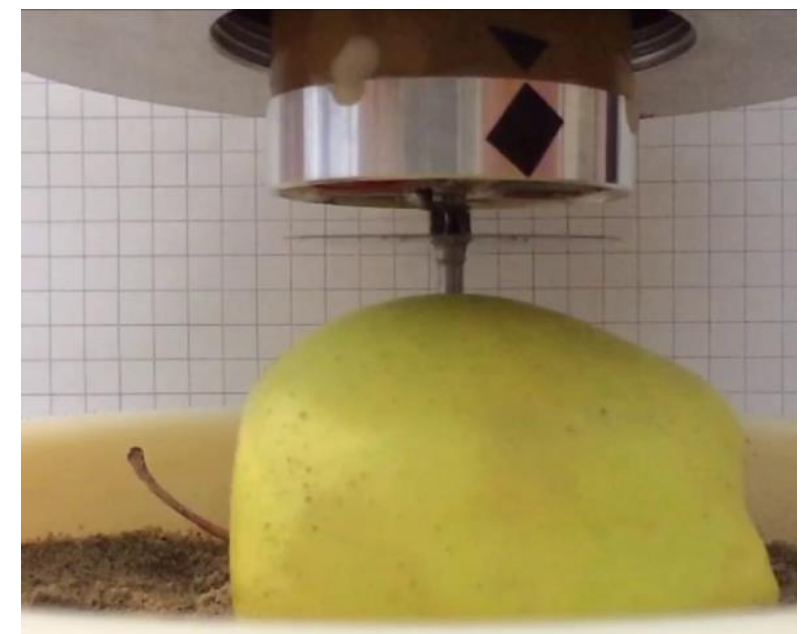

Figure 2 Frame from the video analysis during the registration of the time to failure (TTF) parameter.

$$
E_{D}=\int_{0}^{T} F_{m} \frac{d w}{d t} d t
$$

where ED denotes the dissipated energy (N.mm), while T is the time period of the given load cycle (s). For theoretical calculation, inserting equation (1) and (2) into our previous formula:

$$
E_{D}=\int_{0}^{T} F_{\max }(1-\cos (\omega t))\left(j+\omega w_{\max } \sin (\omega t-\delta)\right) d t .
$$

For the numeric integration of equation (4), the resulted load and deformation data from the cyclic compressive test are available as lookup-table inputs in a Simulink block diagram. During the evaluation of the measurements, the ratio of dissipated energy (Delgadillo and Bahia, 2005) is calculated:

$$
E_{D R}=\frac{\sum_{i=0}^{n} E_{D i}}{E_{D n}}
$$

where EDR is the ratio of dissipated energy (-), $\sum_{\mathrm{i}=0}^{\mathrm{n}} \mathrm{E}_{\mathrm{Di}}$ denotes the sum of dissipated energy at the given load cycle (N.mm), and EDn is the dissipated energy of the last calculated cycle (N.mm).

The peak value of this ratio is used to mark the inner rupture of the fruit material (Figure 3): since this maximum value is clearly connected to the failure mechanism of the crops (Farkas, Fenyvesi and Petróczki, 2019a), it must be included during the correlation analysis.

The viscoelastic behaviour of the examined Golden Delicious apples is investigated with a Simulink-based control loop system. For the identification, the presented measurement data before the rupture point of the fruit material is applied. The measured deformation (wm) and the calculated (w) output of the mathematical model are displayed and compared in one scope (Figure 4).

The Poynting-Thomson body contains two elastic components (E1, E2 - N.mm-1), and one viscous part $(\eta-$ Ns.mm-2). The three-element visoelastic structures are the simplest models, that can handle the creep phenomenon of the given material - where the constant stress is causing an 


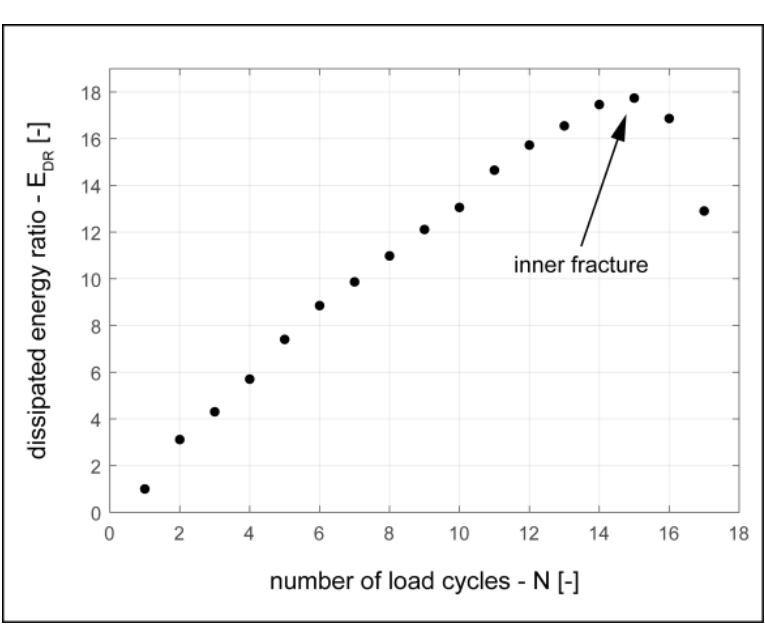

Figure 3 Energy peak related to inner fracture during the fatigue process of Golden apples (Farkas, Fenyvesi and Petróczki 2019a).

increasing trend in the deformation process. With the control loop system and a minimum search method, the three viscoelastic parameters can be determined with the best fit of the calculated deformation to the actual deformation curve (Farkas, Fenyvesi and Petróczki, 2019b).

For our study, Golden Delicious apples were chosen for the experiments, which is representative at the Hungarian food producing and the consumer market.

The measurements were performed on 25 Golden Delicious specimens. Each fruit was loaded in 6 different spots, using different frequency settings, so the described viscoelastic parameters and dissipated energy values were evaluated in 150 cases overall.

The samples were stored in an ambient laboratory environment $\left(\sim 25{ }^{\circ} \mathrm{C}\right.$, with the relative humidity of $\sim 60$ RH\%). The fruit sample parameters were: $\sim 160 \mathrm{~g}( \pm 30 \mathrm{~g})$, density: $\sim 0.875$ g.cm-3 $( \pm 0.03$ g.cm-3). The measurements were performed within the confines of few hours, so degradation and further ripening could be neglected during the investigations.

According to the literature, the most dangerous frequency values were reported under $10 \mathrm{~Hz}$ during the transportation process (Fischer et al., 1992; Hinsch et al, 1993; Vursavuş and Özgüven, 2004), so the frequency values were adjusted in this range: the steps were divided for nearly identical intervals $(2.5,3.7,5,7.5,10$, and $11.6 \mathrm{~Hz}$, respectively) set by practical options on the measuring device.

\section{Statistic analysis}

For the statistical analysis of the measurement data, we used the SPSS statisctics 25 software, where the linear regression tool is applied. To describe the failure time as a function of the measured dissipated energy parameters and the components of the Poynting-Thomson model, multiple linear regression models were examined. For the verification of these models, we used the analysis of variance (ANOVA) method.

\section{RESULTS AND DISCUSSION}

Besides the resulted parameters from the compressive load tests, the applied frequency vales are also considered during our investigations.

From the viscoelastic properties, the viscous part is clearly the most important parameter in the characterization of the failure mechanism. Our previous study showed, that only these values are standing in strong correlation with the frequency settings, but this trend has a non-linear nature (Farkas, Fenyvesi and Petróczki, 2019b). From the aspect of linear description of failure time, the frequency parameters did not appear in any model suggestions (presented in Table 1).

The relationship between the EDRmax values and the TTF parameter is representing the connection of the inner damage of cell structure and the rupture point. This relation could add another important aspect to the model to improve the approximation of the failure behavior in case of pome fruits.

From these variables, there are four regression model is resulted with different coefficients of determination (shown in Table 1). The elastic response of the fruit tissue must determine the failure process as well: in model $3, \mathrm{E}_{1}$ modulus is improving the fit considerably, so this elastic parameter is reasonable to include into the characterization. However, $\mathrm{E}_{2}$ is also increasing the $\mathrm{R}_{2}$ in model no. 4 , the difference between the two options is so small, that this variable just means an unnecessary to describe the elastic behavior - the $E_{1}$ is representing it for the given material

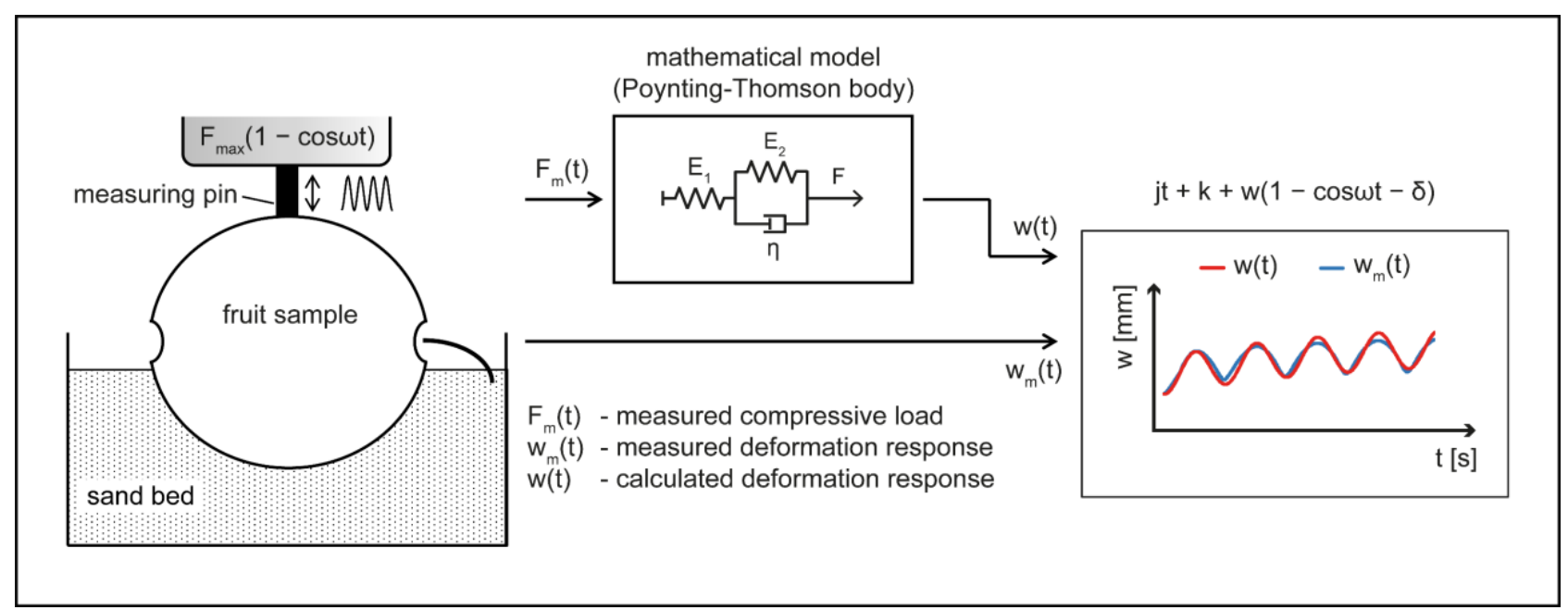

Figure 4 Identification of the Poynting-Thomson viscoelastic model (Farkas, Fenyvesi and Petróczki, 2019b). 
already. Considering these standpoints, model no. 3 is chosen with the following coefficients:

$T T F=0.533+2.736 \eta+0.141 E_{D R \max }-0.261 E_{1}$

We verified the validity of our model with the analysis of variance: the significance level is $p<0.05$, so the resulted model is applicable for the quantitative description of the investigated phenomena (shown in Table 2).

Figure 5 (a) is showing the relationship between the measured time to failure parameters and the predicted values from the applied regression model, while (b) is representing the categories of relative difference, where all the 25 specimens were divided. Most of the examined samples fall into the $5-10 \%$ range of error, the average of difference is $6.20 \%$ in the case of 13 apples. This group is followed by the category of error under $5 \%$, where the average value is $2.61 \%$, the data were obtained from 6 samples. 5 of the investigated apples are showing $12.81 \%$ relative difference, and 1 sample resulted $20.22 \%$ during the comparison of the dependent variable. This consequence about the relative error is composed of three different aspects:

1. The coefficients of the Poynting-Thomson model were also determined with a regression method during the parameter identification (Farkas, Fenyvesi and Petróczki, 2019b). Although the $\mathrm{R}_{2}$ values were fell into the $0.967-0.998$ range when the measured creep data was compared with the Simulink-based visoelastic model, the relatitve error of this approximation cannot be calculated.

2. The registration of the time to failure parameter was performed in a dynamically changing section during the rupture process: the frame analysis also carrying the possibility of error, since the sample rate has its own limitations.

3. The dissipated energy calculations were pointing to the calculation of the EDRmax value, which is indicating the inner rupture of some level, but the accurate background of this

Table 1 Linear regression model summary.

\begin{tabular}{|c|c|c|c|c|c|c|c|c|c|}
\hline \multirow[t]{2}{*}{ Model } & \multirow[t]{2}{*}{$\mathbf{R}$} & \multirow[t]{2}{*}{$\begin{array}{c}\mathbf{R} \\
\text { Square }\end{array}$} & \multirow[t]{2}{*}{$\begin{array}{l}\text { Adjusted } \\
\text { R Square }\end{array}$} & \multirow{2}{*}{$\begin{array}{c}\text { Std. Error } \\
\text { of the } \\
\text { Estimate } \\
\end{array}$} & \multicolumn{5}{|c|}{ Change Statistics } \\
\hline & & & & & $\begin{array}{c}\text { R } \\
\text { Square } \\
\text { Change }\end{array}$ & $\begin{array}{c}\text { F } \\
\text { Change }\end{array}$ & df1 & df 2 & Sig. F Change \\
\hline 1 & $.902(a)$ & .814 & .812 & 1.03413 & .814 & 641.502 & 1 & 147 & .000 \\
\hline 2 & $.963(\mathrm{~b})$ & .927 & .926 & .64922 & .113 & 226.984 & 1 & 146 & .000 \\
\hline 3 & $.971(\mathrm{c})$ & .943 & .941 & .57824 & .015 & 39.039 & 1 & 145 & .000 \\
\hline 4 & $.972(\mathrm{~d})$ & .945 & .943 & .56840 & .002 & 6.064 & 1 & 144 & .015 \\
\hline
\end{tabular}

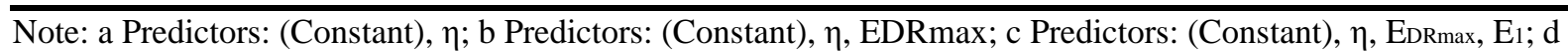
Predictors: (Constant), $\eta$, EDRmax, E1, E2.

Table 2 ANOVA summary of the linear regression model.

\begin{tabular}{lccccc}
\hline \multicolumn{1}{c}{ Model } & Sum of Squares & df & Mean Square & F & Sig. \\
\hline Regression & 794.762 & 3 & 264.921 & 792.307 & 0.000 \\
Residual & 48.483 & 145 & 0.334 & & \\
Total & 843.245 & 148 & & & \\
\hline
\end{tabular}

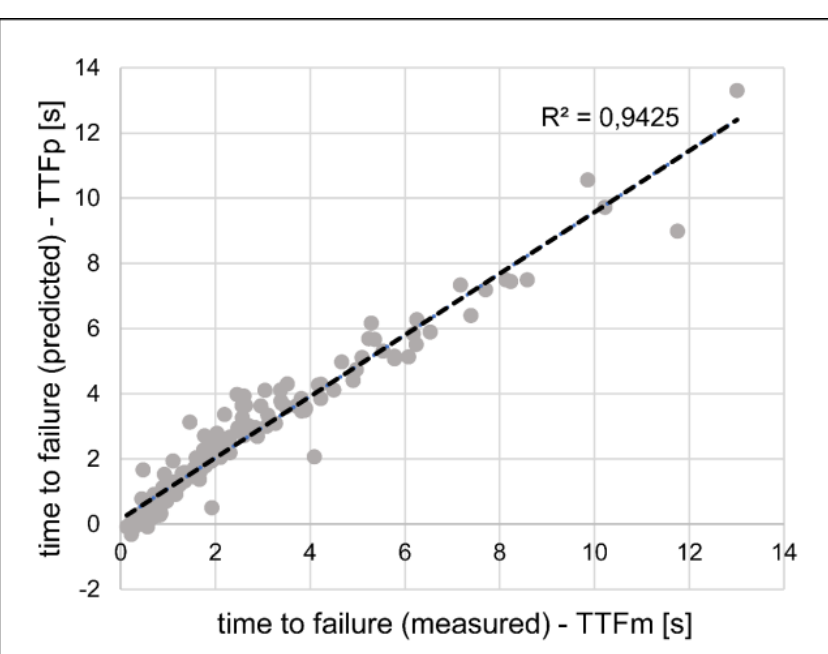

(a)

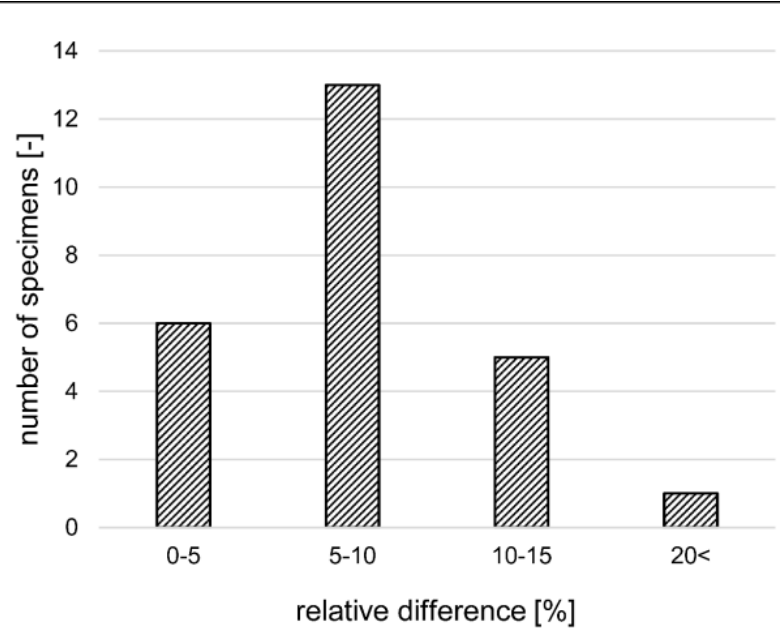

(b)

Figure 5 Relationship between the measured and calculated TTF parameter in case of 150 tests (a). Number of specimens in different relative error categories in case of 25 examined apples (b). 
relationship is still waiting for more investigations. While the circumstances of the cracking propagation e.g. in the area of asphalt pavement is more explored (Sangpetngam, 2003), the role of the dissipated energy ratio in the cellular level is a future plan to investigate in case of different fruit materials.

In the case of our study, the following answers were formed for our hypotheses:

1. A multiple linear regression model with certain visoelastic parameters and a dissipated energy indicator can describe the failure time of Golden Delicious apples with an overall relative difference of $7.22 \%$

2. The frequency settings in the range of $2.5-11.6 \mathrm{~Hz}$ are not influencing the failure time in the resulted linear regression model.

The resulted equation is a simple linear description of the Golden apples' failure mechanism, which can be applied for further transportation studies or cyclic load simulations.

\section{CONCLUSION}

Viscoelastic modelling and dissipated energy calculations are commonly applied methods in the studies about damage susceptibility of different fruits: the parameters from these approaches can be related to the failure mechanism separatel. In our research, we have extended on the previous approaches to supply variables for a multiple regression model at the same time.

The visoelastic coefficients were determined with a custom developed control-loop method, while the dissipated energy calculation was successfully implemented from another research area to the present investigations of fruit materials.

The novel frame-by-frame image analysis allows to gather direct information from a rapidly changing process, supplementing the mathematical approach for registering the rupture phenomenon. Based on the measurement results from the developed methods, our novel, multiple linear regression model can describe the time to failure occasion in case of the examined Golden Delicious apples in the most important frequency range. Also, the presented model can describe the failure characteristics with an acceptable relative difference. It is suggested, that the model can be used for further fruit types. The paper presents a simple three-element material description, but the failure mechanism can be characterized in further experiments, where the visoelastic approximation can be extended with more complex variables.

The current focus of the compressive load settings (which is aimed to reproduce the most dangerous frequencies during the transportation) can also be extended with other load circumstances from other manipulating stages of the food processing chain.

\section{REFERENCES}

Ahmadi, E., Barikloo, H., Kashfi, M. 2016. Viscoelastic finite element analysis of the dynamic behavior of apple under impact loading with regard to its different layers. Computers and Electronics in Agriculture, vol. 121, p. 1-11. https://doi.org/10.1016/j.compag.2015.11.017

Blahovec, J. 1996. Stress relaxation in cherry fruit. Biorheology, vol. 33, no. 6, p. 451-462. https://doi.org/10.1016/S0006-355X(97)00033-4
Bohdziewicz, J., Czachor, G. 2016. Dissipation of Energy in Tissues of Berry Fruit of Selected Plants Species under Cyclic Load Conditions. Agricultural Engineering, vol. 20, no. 4, p. 5-14. https://doi.org/10.1515/agriceng-2016-0059

Ciupak, A., Gładyszewska, B. 2011. Elastic hysteresis determination for the skin of tomato fruit during uniaxial tension test. Teka Commission of motorization and power industry in agriculture. OL PAN, 11, p. 40-47. http://journals.pan.pl/Content/91389/mainfile.pdf

Delgadillo, R., Bahia, H. 2005. Rational fatigue limits for asphalt binders derived from pavement analysis. Asphalt paving technology: Journal of the association of asphalt paving technologics, vol 74, p. 1-42.

Diels, E., Odenthal, T., Keresztes, J., Vanmaercke, S., Verboven, P., Nicolaï, B., Saeys, W., Ramon, H., Smeets, B. 2016. Development of a visco-elastoplastic contact force model and its parameter determination for apples. Postharvest Biology and Technology, vol. 120, p. 157-166. https://doi.org/10.1016/j.postharvbio.2016.06.003

Dintwa, E., Van Zeebroeck, M., Ramon, H., Tijskens, E. 2008. Finite element analysis of the dynamic collision of apple fruit. Postharvest Biology and Technology, vol. 49, no. 2, p. 260-276. https://doi.org/10.1016/j.postharvbio.2008.01.012

Farkas, C., Fenyvesi, L., Petróczki, K. 2019a. Analysis of energy-transport inside pome fruits during repeated compressive load. (Almástermésű gyümölcsökben kialakuló energiatranszport-elemzés ismétlődő terheléssel végzett roncsolásos vizsgálat útján.) Mezőgazdasági Technika, 2019/07, p. 2-5. (in Hungarian)

Farkas, C., Fenyvesi, L., Petróczki, K. 2019b. Identification and Frequency Dependence of Viscoelastic Parameters during Dynamic Creep Tests on Selected Pome Fruits. AgriEngineering, vol. 1, no. 3, p. 324-331. https://doi.org/10.3390/agriengineering1030024

Fenyvesi, L. 2007. Physical and Mechanical Characteristics of Fruit Damages. In Sitkei, Gy. Technical aspects of horticultural production. Gödöllö: Hungarian Institute of Agricultural Engineering. p. 108-141. ISBN-963-611-436-6

Ferreira, M., Sargent, S., Brecht, J., Chandler, C. 2008. Strawberry fruit resistance to simulated handling. Scientia Agricola, vol. 65, no. 5, p. 490-495. https://doi.org/10.1590/S0103-90162008000500007

Fischer D., Craig, W. L., Watada, A. E., Douglas, W., Ashby, B. H. 1992. Simulated In-Transit Vibration Damage to Packaged Fresh Market Grapes and Strawberries. Applied Engineering in Agriculture, vol. 8, no. 3, p. 363-366. https://doi.org/10.13031/2013.26078

Gnedenko, B., Pavlov, I., Ushakov I., Chakravarty, S., 1999. Statistical reliability engineering. New York: John Wiley \& Sons Inc. ISBN-978-0-471-12356-9. https://doi.org/10.1002/9780470172407

Gorji Chakespari, A., Rajabipour, A., Mobli, H. 2010. Anisotropic Relaxation and Creep Properties of Apple (cv. Shafi Abadi and Golab Kohanz). Advance Journal of Food Science and Technology, vol. 2, no. 4, p. 200-205. https://doi.org/10.5539/jas.v2n3p61

Hinsch, R. T., Slaughter, D. C., Craig, W. L., Thompson, J. F. 1993. Vibration of Fresh Fruits and Vegetables During Refrigerated Truck Transport. Transactions of the ASAE, vol. 36, no. 4, p. 1039-1042. https://doi.org/10.13031/2013.28431

Hussein, Z., Fawole, O., Opara, U. 2018. Preharvest factors influencing bruise damage of fresh fruits - a review. Scientia Horticulturae, vol. $229, \quad$ p. $\quad 45-58$. https://doi.org/10.1016/j.scienta.2017.10.028

Kahirdeh, A., Khonsari, M. 2015. Energy dissipation in the course of the fatigue degradation: Mathematical derivation and 
experimental quantification. International Journal of Solids $\begin{array}{llll}\text { and Structures, } & \text { vol. 77, p. 74-85. }\end{array}$ https://doi.org/10.1016/j.ijsolstr.2015.06.032

Kim, J., Roque, R., Birgisson, B. 2006. Interpreting Dissipated Energy from Complex Modulus Data. Road Materials and Pavement Design, vol. 7, no. 2, p. 223-245. https://doi.org/10.1080/14680629.2006.9690034

Lee, J., Tan, J., Waluyo, S. 2012. Measurement of Dynamic Compressive Properties of Apples using the Oscillatory Test. Journal of Biosystems Engineering, vol. 37, no. 1, p. 28-35. https://doi.org/10.5307/JBE.2012.37.1.028

Lee, J., Tan, J., Waluyo, S. 2016. Hysteresis characteristics and relationships with the viscoelastic parameters of apples. Engineering in Agriculture, Environment and Food, vol. 9, no. 1, p. 36-42. https://doi.org/10.1016/j.eaef.2015.09.005

Lien, C., Ting, C. 2014. Assessing guava maturity by statistical analyses of dropped fruit impact responses. Postharvest Biology and Technology, vol. 95, p. 20-27. https://doi.org/10.1016/j.postharvbio.2014.03.013

McLaughlin, N. B., Pitt, R. E. 1984. Failure Characteristics of Apple Tissue Under Cyclic Loading. Transactions of the ASAE, vol. 27, no. 1, p. 311-320. https://doi.org/10.13031/2013.32782

Miraei Ashtiani, S., Sadrnia, H., Mohammadinezhad, H., Aghkhani, M., Khojastehpour, M. and Abbaspour-Fard, M. 2019. FEM-based simulation of the mechanical behavior of grapefruit under compressive loading. Scientia Horticulturae, $\begin{array}{llll}\text { vol. } & 245, & \text { p. } & 39-46 .\end{array}$ https://doi.org/10.1016/j.scienta.2018.10.006

Mohsenin, N. (1986). Physical properties of plant and animal materials. Amsterdam: Gordon and Breach Science Publishers. ISBN-067-721-370-0

Petróczki, K., Fenyvesi, L. 2014. Improvement of compressive testing instrument with wide range of speed for examining agricultural materials. Computers and Electronics in Agriculture, vol. 101, p. 42-47. https://doi.org/10.1016/j.compag.2013.12.003

Pillinger, G., Géczy, A., Hudoba, Z., Kiss, P. 2018. Determination of soil density by cone index data. Journal of

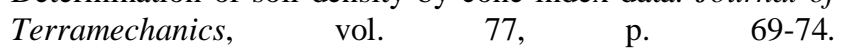
https://doi.org/10.1016/j.jterra.2018.03.003

Sangpetngam, B. 2003. Development and evaluation of a viscoelastic boundary element method to predict asphalt pavement cracking. University of Florida. https://archive.org/details/developmentevalu00sang/page/n22

Sitkei, G. 1986. Mechanics of agricultural materials. Budapest: Akadémiai Kiadó. ISBN- 978-044-460-103-2

Springael, J., Paternoster, A., Braet, J. 2018: Reducing postharvest losses of apples: Optimal transport routing (while minimizing total costs). Computers and Electronics in Agriculture, vol. 146, p. 136-144. https://doi.org/10.1016/j.compag.2018.02.007

Stropek, Z., Gołacki, K. 2013. The effect of drop height on bruising of selected apple varieties. Postharvest Biology and $\begin{array}{lllll}\text { Technology, vol. } & 85, & \text { p. } & 167-172 .\end{array}$ https://doi.org/10.1016/j.postharvbio.2013.06.002

Tscheuschner, H., Doan, D. 1988. Modelling of mechanical properties of apple flesh under compressive load. Journal of
Food Engineering, vol. 8, no. 3, p. 173-186. https://doi.org/10.1016/0260-8774(88)90052-0

Vursavus, K., Kesilmis, Z., Oztekin, B. 2017. Nondestructive dropped fruit impact test for assessing tomato firmness. Chemical Engineering Transactions, vol. 58, p. 325-330 https://doi.org/10.3303/CET1758055

Vursavuş, K., Özgüven, F. 2004. Determining the Effects of Vibration Parameters and Packaging Method on Mechanical Damage in Golden Delicious Apples. Turkish Journal of Agriculture and Forestry, vol. 28, p. 311-320.

Wang, W., Yang, Z., Lu, H., Fu, H. 2018. Mechanical damage caused by fruit-to-fruit impact of litchis. IFACPapersOnLine, vol. 51, no. 17, p. 532-535. https://doi.org/10.1016/j.ifacol.2018.08.154

Wang, Y., Wang, J., Yao, C., Lu, Q. 2009. Firmness measurement of peach by impact force response. Journal of Zhejiang University SCIENCE B, vol. 10, no. 12, p. 883-889. https://doi.org/10.1631/jzus.B0920108

Yousefi, S., Farsi, H., Kheiralipour, K. 2016. Drop test of pear fruit: Experimental measurement and finite element modelling. Biosystems Engineering, vol. 147, p. 17-25. https://doi.org/10.1016/j.biosystemseng.2016.03.004

Zhao, W., Fang, Y., Zhang, Q., Guo, Y., Gao, G., Yi, X. 2017. Correlation analysis between chemical or texture attributes and stress relaxation properties of 'Fuji' apple. Postharvest Biology and Technology, vol. 129, p. 45-51. https://doi.org/10.1016/j.postharvbio.2017.03.010

\section{Acknowledgments:}

The DyMaTest instrument was provided by the Institute of Agricultural Engineering, Gödöllő. The authors thank László Székely and László Földi for their supporting work. This research received no external funding.

\section{Contact address:}

*Csaba Farkas, Szent István University, Faculty of Mechanical Engineering, Department of Measurement Technology, 2100 Gödöllö, Páter Károly utca 1.

Tel.: +36 28522 000/1532,

E-mail: farkas.csaba@gek.szie.hu

ORCID: https://orcid.org/0000-0002-0832-9973

László Fenyvesi, Szent István University, Faculty of Mechanical Engineering, Department of Agricultural Engineering, 2100 Gödöllö, Páter Károly utca 1.

Tel.: +3628522 610,

E-mail: fenyvesi.laszlo@gek.szie.hu

ORCID: https://orcid.org/0000-0002-4657-5868

Károly Petróczki, Szent István University, Faculty of Mechanical Engineering, Department of Measurement Technology, 2100 Gödöllő, Páter Károly utca 1.

Tel.: +36 28522 000/1468,

E-mail: petroczki.karoly@gek.szie.hu

ORCID: https://orcid.org/0000-0003-3331-8499

Corresponding author: * 